\title{
Characterization of heat tolerance in wheat cultivars and effects on production components ${ }^{1}$
}

\author{
Adérico Júnior Badaró Pimentel*2, João Romero do Amaral Santos de Carvalho Rocha ${ }^{3}$, \\ Moacil Alves de Souza ${ }^{4}$, Guilherme Ribeiro ${ }^{5}$, Carolina Ramalho Silva ${ }^{3}$, Isadora Cristina Martins Oliveira ${ }^{3}$ \\ http://dx.doi.org/10.1590/0034-737X201562020009
}

\begin{abstract}
There is a need for heat tolerant wheat cultivars adapted to the expansion of cultivation areas in warmer regions due to the high demand of this cereal for human consumption. The objective of this study was to evaluate the effect of high temperatures on grain yield and yield components of wheat and characterize heat tolerant wheat genotypes at different development stages. The genotypes were evaluated in the field with and without heat stress. High temperatures reduced the number of spikelets per spike (21\%), number of grains per spike (39\%), number of grains per spikelet (23\%), 1000-grain weight (27\%) and grain yield (79\%). Cultivars MGS 1 Aliança, Embrapa 42, IAC 24-Tucuruí and IAC 364-Tucuruí III are the most tolerant to heat stress between the stages double ridge and terminal spikelet; MGS 1 Aliança, BRS 264, IAC 24-Tucuruí, IAC 364-Tucuruí III and VI 98053 , between meiosis and anthesis; and BRS 254, IAC-24-Tucuruí, IAC-364-Tucuruí III and VI 98053, between anthesis and physiological maturity. High temperatures reduce grain yield and yield components. The number of grains per spike is the most reduced component under heat stress. The genotypes differed in tolerance to heat stress in different developmental stages.
\end{abstract}

Key words: Triticum aestivum, genetic improvement, abiotic stress, high temperature

\section{RESUMO}

\section{Caracterização de cultivares de trigo para tolerância ao calor e seus efeitos sobre alguns componentes da produção}

A necessidade de obtenção de cultivares de trigo tolerantes ao calor, para a consequente expansão da área de cultivo para regiões mais quentes, é premente, diante da alta demanda desse cereal para alimentação humana. O objetivo deste trabalho foi avaliar o efeito da temperatura elevada sobre a produtividade de grãos de trigo e os componentes da produção, além de caracterizar genótipos de trigo quanto à tolerância ao calor em diferentes estádios de desenvolvimento. Os genótipos foram avaliados em campo, em presença e ausência de estresse de calor. A temperatura elevada reduziu o número de espiguetas/espiga (21\%), número de grãos por espiga (39\%), número de grãos por espigueta (23\%), massa de mil grãos (27\%) e produtividade de grãos (79\%). Os cultivares MGS 1 Aliança, Embrapa 42, IAC 24-Tucuruí e IAC 364-Tucuruí III são mais tolerantes ao estresse de calor entre o estádio de duplo anel e espigueta terminal; MGS 1 Aliança, BRS 264, IAC 24-Tucuruí, IAC 364-Tucuruí III e VI 98053, entre a meiose e a antese; e BRS 254, IAC 24-Tucuruí, IAC 364-Tucuruí III e VI 98053, entre a antese e a maturação

\footnotetext{
Received on 04/06/2013 and approved on 27/02/2015.

${ }^{1}$ Research financially supported by CNPq.

${ }^{2}$ Universidade Federal de Viçosa, Departamento de Fitotecnia, Viçosa, Minas Gerais, Brasil. adericojr@yahoo.com.br

Universidade Federal de Viçosa, Departamento de Fitotecnia, Viçosa, Minas Gerais, Brasil. joao.rocha@ufv.br; carolsilvapf@yahoo.com.br; isadora.martins@ufv.br

${ }^{4}$ Universidade Federal de Viçosa, Departamento de Fitotecnia, Viçosa, Minas Gerais, Brasil. moacil@ufv.br

${ }^{5}$ Universidade Federal do Pampa, Faculdade de Agronomia, Itaqui, Rio Grande do Sul, Brasil. guilhermeribeiro@unipampa.edu.br

Corresponding author: adericojr@yahoo.com.br
} 
fisiológica. A temperatura elevada diminui a produtividade de grãos e os componentes da produção. O número de grãos/espiga é o componente que mais se reduz sob condições de estresse de calor. Os genótipos de trigo diferem quanto ao estádio fenológico em que são mais tolerantes ao estresse de calor.

Palavras-chave: Triticum aestivum, melhoramento genético, estresse abiótico, temperatura elevada.

\section{INTRODUCTION}

Given the growing demand of wheat for human consumption, which is estimated to grow at $1.6 \%$ per year by 2020 (Ortiz et al., 2008), the wheat crop has been occupying areas considered marginal for the full development of the species. These areas are often located in regions of lower latitude where the heat stress is the main factor limiting grain production (Lillemo et al., 2005). This fact makes the heat tolerance one of the main objectives of wheat breeding programs in the world (Mohammadi et al., 2008).

Historically, Brazil is one of the largest wheat importers. In the last five harvests, the average production was 5.32 million tons, as against an estimated consumption of 10.48 million tons (CONAB, 2014). The South Region accounts for about $95 \%$ of the wheat produced in the country; the remaining is obtained from areas of expanding wheat cultivation in the Southeast and Center-West regions, especially in the Brazilian Cerrado.

Wheat grown in the cerrado has a number of advantages over other producing regions such as superior grain quality and yield; possibility of rainfed and irrigated cultivation and increased price competitiveness in the domestic market. However, the cerrado production is not relevant on the national scene, as the cultivated area is limited by the occurrence of temperatures higher than ideal for the crop development.

Heat stress is defined as the increase in temperature above a critical threshold for a period of time sufficient to cause irreversible damage to plant growth and development (Wahid et al., 2007). In the case of wheat, both long hours of exposure to moderately high temperatures (22 to $28{ }^{\circ} \mathrm{C}$ ) and short exposures to very high temperatures $\left(>30^{\circ} \mathrm{C}\right)$ affect crop development and reduce grain yield (Stone \& Nicolas, 1995; Souza \& Pimentel, 2013). Much of this reduction is due to losses in primary yield components (Yildirim \& Bahar, 2010). Industrial quality is also negatively influenced (Labuschagne et al., 2009), given that heat stress compromises the length of the protein accumulation period and the deposition of starch.

Knowing the magnitude of heat damage in the different stages of crop development, in which the yield components are defined, is essential for high grain yields. This information is relevant for the crop breeding, so that greater gains can be achieved by increasing the tolerance, primarily, in the stages in which the crop is more sensitive.

At the same time, the identification of heat tolerant genotypes, in different phases, enables breeding schemes to combine favorable alleles present in different cultivars and produce inbred lines with higher performance than the parental lines.

Genetic variability of grain yield and its components, as a function of different genotype responses to heat in different stages of wheat development, was reported by Lillemo et al. (2005) \& Yildirim \& Bahar (2010). According to Reynolds et al. (1994), the grain mass is the most important character to confer heat tolerance. On the other hand, Shpiler \& Blum (1986) found that, under heat stress, the variation among genotypes for grain yield is due to a larger variation in number of spikelets per spike and number of grains per spikelet. These characters, along with ear length, were appointed by Farooq et al. (2011a) as essential for the breeder engaged in the selection of heat tolerant genotypes.

The relative importance of traits can vary as a function of genotype and intensity, duration and time of occurrence of the stress. Cunha et al. (1996) found that in adverse growing conditions, different genotypes use different strategies to compose the final grain yield.

In this context, the aim of this study was to evaluate the effect of high temperature on grain yield and yield components, as well as to characterize wheat genotypes for heat tolerance at different stages of development.

\section{MATERIALS AND METHODS}

Cultivars MGS 1 Aliança, Anahuac 75, BRS 254, BRS 264, Embrapa 42, IAC 24-Tucuruí, IAC 364-Tucuruí III, UFT 1 Pioneiro and the line VI 98053 were evaluated in the field, in the absence and in the presence of heat stress, in 2012. The trials with stress and without stress were conducted respectively in the experimental stations of the Federal University of Viçosa located in CoimbraMG (2051'25"S, 42 $48^{\prime} 10^{\prime \prime} \mathrm{O}, 720 \mathrm{~m}$ altitude) and Viçosa $\left(20^{\circ} 45^{\prime} 14^{\prime \prime} \mathrm{S}, 42^{\circ} 52^{\prime} 55^{\prime \prime} \mathrm{O}, 648 \mathrm{~m}\right.$ altitude). 
The stress condition was produced by cultivating wheat during the summer-autumn season, during which high temperatures prevail throughout the crop cycle. Seeds were sown on February 17 and harvest was carried out on May 18. The cultivation without stress was conducted during the autumn-winter season, with sowing on 25 May and harvest on September 18. This period is recommended for irrigated wheat in the State of Minas Gerais (Comissão, 2011) due to favorable temperatures for the crop development.

Because the heat stress is the only effect to be evaluated on genotype expression, the cultural practices were the same in both conditions, in order to reduce to the most the influence of other biotic and abiotic factors. The sowing fertilization was $300 \mathrm{~kg} \mathrm{ha}^{-1}$ of compost and the 08-28-16 formula applied in the furrows. At the beginning of tillering, $250 \mathrm{~kg} \mathrm{ha}^{-1}$ of ammonium sulfate as $\mathrm{N}$ source was applied by topdressing. Chemical weed control was carried out at 15 days after planting with the herbicide Metsulfuron, using $5 \mathrm{~g} \mathrm{ha}^{-1}$ of the commercial product. The experiment without stress was conducted with full irrigation, whereas under the stress condition, additional irrigation was provided when needed, since the experiment was conducted in rainy season. Daily records of maximum, medium and minimum temperatures were obtained from the weather station at the site.

Both experiments were arranged in a randomized complete block design, with two replications for the condition without stress and three for the condition with stress. The plots consisted of five $5 \mathrm{~m}$-long rows, seeding rate of 350 seeds per $\mathrm{m}^{2}$, and the tree central lines as harvest area. Data were collected from the harvest area on the following characters: i) number of spikelets per spike, from the average number of spikelets in ten ears taken at random from the harvest area in the plots; ii) number of grains per spike, from the average grain number in ten ears harvested at random from the harvest area in the plots; iii) number of grains per spikelet, by dividing the number of grains per spike by the number of spikelets per spike; iv) 1000-grain weight, from the average mass of four 100-grain samples multiplied by $10 ; \mathrm{v}$ ) grain yield, after processing and drying of grain to approximately $13 \%$ moisture; vi) cycle, the number of days between seedling emergence and physiological grain maturity recorded from 50 plants in the plot, according to the phenological scale proposed by Zadoks et al. (1974).

Data were examined by the individual and combined variance analysis and means were compared by the Tukey test using the Statistical Analysis System (SAS), version 9.1 (SAS Institute, 2003).
Quantification of heat stress effects in the unfavorable condition in relation to the favorable condition was obtained by the reduction percentage (\% $\mathrm{R})$ using the equation $\% \mathrm{R}=\left[1-\frac{\mathrm{p}_{\mathrm{c}}}{\mathrm{p}_{\mathrm{s}}}\right] * 100$, where $\mathrm{p}_{\mathrm{c}}$ and $\mathrm{p}_{\mathrm{s}}$ are the means for each genotype in the conditions with and without stress, respectively, for each trait. Based on this methodology, genotypes with lower reduction percentage are considered more tolerant because of their ability to maintain their performance in the presence of stress.

To classify the cultivars according the degree of heat tolerance, we used the index proposed by Fischer \& Mauer (1978): IFM $=\frac{\left(1-Y / Y_{p}\right)}{D}$, where $Y$ and $Y_{p}$ are the means of each genotype with and without stress, respectively. $\mathrm{D}=1-\frac{\mathrm{X}}{\mathrm{X}_{\mathrm{p}}}$ is equivalent to stress intensity, with $\mathrm{X}$ being the mean of all genotypes in the environment with stress and $X_{p}$ the mean of all genotypes in the environment without stress. Genotypes with IFM $\leq 0.5$ have high heat tolerance; those with IFM between 0.5 and 1.0 have moderate tolerance and IFM > 1.0 are sensitive to heat.

\section{RESULTS AND DISCUSSION}

Temperatures recorded during the summer-autumn crop (Table 1) characterized the expected condition of heat stress, with higher values than those observed for the condition without stress, regardless of plant development stage. Thus, differences in genotype performances between the two seasons are mainly due to heat stress.

The individual variance analysis for the stress-free condition showed significant effect of genotype for the traits number of spikelets per spike, number of grains per spike, number of grains per spikelet and cycle. In the stress condition, there was significant effect for number of grains per spikelet, grain yield and cycle (Table 2). Once the homogeneity of residual variances between growing conditions was verified by the Fmax test, which considers the residual variances as homogeneous when the ratio between the residual mean squares does not exceed the value 7 (Pimentel-Gomes, 2000), the combined analysis of variance was carried out.

The combined analysis of variance (Table 3 ) showed significant effect for the source of variation environment for all traits, indicating that the heat stress influenced the expression of the traits. Grain yield decreased from $2841 \mathrm{~kg} \mathrm{ha}^{-1}$, in favorable conditions, to $588 \mathrm{~kg} \mathrm{ha}^{-1}$ in the stress condition, hence, an average reduction of $79 \%$. As it was confirmed in this study, a reduction in grain 
yield, from 60 to $95 \%$, is reported in the literature (Albrecht et al., 2007; Yildirim \& Bahar, 2010).

One of the main reasons for the deleterious effect of high temperatures is the photosynthesis inhibition (Taiz \& Zeiger, 2004). Consequently, carbohydrate reserves drop and organs lose sugars, causing decrease in production.
The overall mean of yield components (Table 2) also decreased as a function of the heat stress. The number of grains per spike was the most affected (39\%), above the percentages of reduction observed for the number of spikelets per spike (21\%), number of grains per spikelet $(23 \%)$ and 1000-grain weight (27\%). Eight of the nine genotypes had the largest decrease for the

Table 1. Averages of medium, maximum and minimum temperatures $\left({ }^{\circ} \mathrm{C}\right)$ recorded at different development stages of wheat grown with and without heat stress. Viçosa (MG), 2012

\begin{tabular}{lccc}
\hline \multirow{2}{*}{ Development stage } & Medium & Maximum & Minimum \\
\cline { 2 - 4 } & & Cultivation without stress & 11.7 \\
\hline Emergence/Tillering & 16.0 & 23.2 & 10.4 \\
Tillering/Heading & 15.4 & 23.4 & 12.2 \\
Heading/Maturation & 17.5 & 26.3 & 11.3 \\
Full cycle & 16.3 & 24.6 & 17.5 \\
\hline & & Cultivation with stress & 18.4 \\
\hline Emergence/Tillering & 22.6 & 30.6 & 16.6 \\
Tillering/Heading & 21.8 & 28.0 & 17.5 \\
Heading/Maturation & 20.4 & 27.3 & 28.1 \\
Full cycle & 21.4 & &
\end{tabular}

Table 2. Summary of individual variance analysis for the traits number of spikelets per spike (NSS), number of grains per spike (NGS), number of grains per spikelet (NGSL), 1000-grain weight (TGW), grain yield (YIE) and cycle (CYC) evaluated in wheat cultivars grown in environment with and without heat stress. Viçosa (MG), 2012

\begin{tabular}{|c|c|c|c|c|c|c|}
\hline Trait & Environment & ce of Variation & DF & Mean Squares & Mean & $\mathrm{CV}(\%)$ \\
\hline \multirow{4}{*}{ NSS } & Without stress & Genotype & 8 & $2.37^{*}$ & 19.17 & 3.74 \\
\hline & & Residue & 8 & 0.51 & & \\
\hline & With stress & Genotype & 8 & $4.23^{\mathrm{ns}}$ & 15.07 & 10.15 \\
\hline & & Residue & 16 & 2.34 & & \\
\hline \multirow{4}{*}{ NGS } & Without stress & Genotype & 8 & $104.00 * *$ & 54.17 & 5.81 \\
\hline & & Residue & 8 & 9.89 & & \\
\hline & With stress & Genotype & 8 & $35.17^{\mathrm{ns}}$ & 32.89 & 12.42 \\
\hline & & Residue & 16 & 16.69 & & \\
\hline \multirow{4}{*}{ NGSL } & Without stress & Genotype & 8 & $0.35^{* *}$ & 2.85 & 4.53 \\
\hline & & Residue & 8 & 0.02 & & \\
\hline & With stress & Genotype & 8 & $0.42 * *$ & 2.21 & 9.30 \\
\hline & & Residue & 16 & 0.04 & & \\
\hline \multirow{4}{*}{ TGW (g) } & Without stress & Genotype & 8 & $5.75^{\mathrm{ns}}$ & 39.33 & 4.32 \\
\hline & & Residue & 8 & 2.89 & & \\
\hline & With stress & Genotype & 8 & $8.58^{\mathrm{ns}}$ & 28.78 & 6.90 \\
\hline & & Residue & 16 & 3.94 & & \\
\hline \multirow{4}{*}{ YIE $\left(\mathrm{kg} \mathrm{ha}^{-1}\right)$} & Without stress & Genotype & 8 & $380,583.00^{\text {ns }}$ & 2841.00 & 15.47 \\
\hline & & Residue & 8 & $193,239.39$ & & \\
\hline & With stress & Genotype & 8 & $167,026.42 * *$ & 588.22 & 16.34 \\
\hline & & Residue & 16 & 9238.78 & & \\
\hline \multirow{4}{*}{ CYC (days) } & Without stress & Genotype & 8 & $25.81 * *$ & 98.05 & 0.91 \\
\hline & & Residue & 8 & 0.81 & & \\
\hline & With stress & Genotype & 8 & $39.92 * *$ & 72.15 & 3.60 \\
\hline & & Residue & 16 & 6.76 & & \\
\hline
\end{tabular}

\footnotetext{
**, *: Significant at 1 and 5\% probability, respectively, by the $\mathrm{F}$ test. ${ }^{\text {ns: }}$ non significant.
}

Rev. Ceres, Viçosa, v. 62, n.2, p. 191-198, mar-abr, 2015 
component number of grains per ear (Table 4). It is clear, therefore, that this is the most affected trait by the heat stress.

The reduction in the number of grains per spike can be attributed to the heat effect on the differentiation of floral organs, male and female sporogenesis, pollination and fertilization (Farooq et al., 2011b). High temperatures affect pollen viability, reducing the number of fertilized flowers (Rahman et al., 2009). Similar results were observed by Yildirim \& Bahar (2010); the number of grains per spike decreased from 33 in the ideal condition of cultivation to 13 in heat stress condition. Under the same conditions, the grain mass reduced from $43 \mathrm{~g}$ to $14 \mathrm{~g}$.

Reduction between 21 and $35 \%$ in grain mass was reported by Assad \& Paulsen (2002). Later, Shah \& Paulsen (2003) found that the reduction under stress results from the decrease in the photosynthetic rate of the flag leaf and early leaf senescence. In addition to the damage caused to photosynthesis, starch deposition in grain is reduced because the enzymes involved in the biosynthesis of starch are sensitive to high temperatures (Denyer et al., 1994).

Table 3 shows that there is significant interaction between genotypes and environments for the traits number of grains per spike, number of grains per spikelet and grain yield. This indicates that the genotypes have different performance when subjected to different environments, i.e., they express different degrees of heat tolerance (Table 4).

A practical approach to identifying heat-tolerant genotypes is to use tolerance indices, which measure the ability of genotypes to maintain their productive potential in stress conditions. The indices \% R (Wardlaw et al., 1989) and IFM (Fischer \& Mauer, 1978) are used in wheat breeding programs for heat tolerance (KhannaChopra \& Viswanathan, 1999; Rahman et al., 2009; Oliveira et al., 2011).

The percentage reduction (Table 4) and IFM (Table 5) indicate that the cultivars MGS 1 Aliança, Embrapa
42, IAC 24-Tucuruí and IAC 364-Tucuruí III were moderately tolerant to heat for the trait number of spikelets per spike; MGS 1 Aliança, BRS 264, IAC 24Tucuruí, IAC 364-Tucuruí III and VI 98053, for number of grains per spike; BRS 254, IAC 24-Tucuruí, IAC 364Tucuruí III and VI 98053, for 1000-grain weight; Anahuac 75, BRS 254 and VI 98053, for grain yield; and MGS 1 Aliança, Anahuac 75, IAC 24-Tucuruí, UFT 1 Pioneiro and VI 98053, for cycle. MGS 1 Aliança was tolerant and BRS 264, IAC-364 Tucuruí III and VI 98053 moderately tolerant for number of grains per spikelet.

In this study, the yield components are defined at different stages of the crop cycle. The number of spikelets per spike is defined between the stages double ridge and terminal spikelet, generally between day 30 and day 45 after germination. The number of grains per spike results from the number of spikelets formed and the number of fertilized flowers, the latter being defined between meiosis and anthesis. The 1000-grain weight is defined between anthesis and physiological maturity of the grains. Thus, we infer that the genotypes that stand out for a given component have increased heat tolerance at the stage in which this component is defined.

It was found that the cultivars MGS 1 Aliança, Embrapa 42, IAC-24-Tucuruí and IAC 364-Tucuruí-III are more tolerant to heat between the stages double ridge and terminal spikelet; MGS 1 Aliança, BRS 264, IAC24-Tucuruí, IAC-364-Tucuruí III and the line VI 98053, between meiosis and anthesis; BRS 254, IAC-24-Tucuruí, IAC-364-Tucuruí III and VI 98053, between anthesis and physiological maturity. Since for the overall mean the most affected trait was the number of grains per spike, it can be affirmed that the crop is more sensitive to heat between the stages double ridge and anthesis, in the environmental conditions and with the genotypes used in this study.

Cycle duration is a function of the thermal time sum necessary for the development of each genotype. In the stress condition, the cycle of the cultivars was reduced due to the higher temperatures. The shortening of the

Table 3. Joint analysis of variance for the traits number of spikelets per spike (NSS), number of grains per spike (NGS), number of grains per spikelet (NGSL), 1000-grain weight (TGW), grain yield (YIE) and cycle to maturity (CYC) of wheat cultivars. Viçosa (MG), 2012

\begin{tabular}{lrclllll}
\hline Source of variation & \multicolumn{7}{c}{ Mean Squares } \\
\cline { 2 - 8 } & DF & NSS & NGS & NGSL & TGW & \multicolumn{1}{c}{ YIE } & CYC \\
\hline Genotype (G) & 8 & $5.63^{*}$ & $98.51^{* *}$ & $0.63^{* *}$ & $5.78^{\text {ns }}$ & $319,884.82^{* *}$ & $52.83^{* *}$ \\
Environment (A) & 1 & $180.89^{* *}$ & $4,889.63^{* *}$ & $4.44^{* *}$ & $1,203.33^{* *}$ & $54,810,083.33^{* *}$ & $7,248.89^{* *}$ \\
G x A & 8 & $0.60^{\text {ns }}$ & $54.41^{* *}$ & $0.12^{* *}$ & $7.98^{\text {ns }}$ & $270,435.92^{* *}$ & $10.07^{\text {ns }}$ \\
Residue & 24 & 1.73 & 14.42 & 0.03 & 3.59 & $70,572.31$ & 4.77 \\
\hline CV $(\%)$ & & 7.88 & 9.17 & 7.45 & 5.74 & 17.84 & 2.65 \\
Mean & & 16.71 & 41.40 & 2.47 & 33.00 & 1489.33 & 82.51 \\
\hline
\end{tabular}

**, *: Significant at 1 and 5\% probability, respectively, by the $\mathrm{F}$ test. ${ }^{\text {ns: }}$ : non significant. 
phenological cycle is considered by some authors as the main effect of high temperatures on the development of wheat. Acevedo et al. (1991) reported 50\% reductions in the duration of the vegetative stage, when the temperature increased from $12.2{ }^{\circ} \mathrm{C}$ to $27.5{ }^{\circ} \mathrm{C}$. According to McMaster (1997), the reduction in the time between emergence and double ridge and between double ridge and anthesis causes a reduction in the number of spikelets per spike and number of grains per spikelet.

Under heat stress, the line VI 98053 and cultivars IAC24-Tucuruí and IAC364-Tucuruí III stood out for being moderately tolerant to heat for most traits. Cultivar BRS 254 showed higher grain yield than the others, including the cultivars with better adaptation to heat, MGS 1 Aliança and Anahuac 75 (Table 4). In a study evaluating a group of cultivars in 16 environments in Minas Gerais, Goiás and the Federal District, Albrecht et al. (2007) found that BRS 254 had superior performance under adverse conditions, recommending its cultivation in unfavorable environments.

In addition to be more productive, BRS 254 showed low mass reduction for 1000-grain weight and the largest percentage reduction for cycle (Table 4). In trials conducted during the summer, this cultivar also stood out for the trait 1000-grain weight, with values similar to those of the cultivar adapted to the condition of high temperature (Moraes et al., 2008).

Table 4. Means of number of spikelets per spike (NSS), number of grains per spike (NGS), number of grains per spikelet (NGSL), 1000-grain weight (TGW), grain yield (YIE) and cycle (CYC) and their respective reduction percentages (\% R) of wheat cultivars evaluated in the conditions with and without heat stress. Viçosa (MG), 2012(1)

\begin{tabular}{|c|c|c|c|c|c|c|}
\hline \multirow{2}{*}{ Cultivar } & NSS & NGS & NGSL & TGW (g) & YIE (kg ha-1) & CYC (days) \\
\hline & \multicolumn{4}{|c|}{ Cultivation without stress } & & \\
\hline MGS 1 Aliança & $19.5 \mathrm{ab}$ & $42.5 \mathrm{~d}$ & $2.2 \mathrm{~d}$ & $41.0 \mathrm{a}$ & $3320.0 \mathrm{a}$ & $94.0 \mathrm{c}$ \\
\hline Anahuac 75 & $21.0 \mathrm{a}$ & $60.5 \mathrm{ab}$ & $3.0 \mathrm{abc}$ & $39.0 \mathrm{a}$ & $1935.5 \mathrm{a}$ & $104.5 \mathrm{a}$ \\
\hline BRS 254 & $19.0 \mathrm{ab}$ & $61.0 \mathrm{a}$ & $3.2 \mathrm{ab}$ & $38.0 \mathrm{a}$ & $2948.0 \mathrm{a}$ & $97.0 \mathrm{bc}$ \\
\hline BRS 264 & $18.0 \mathrm{~b}$ & $59.0 \mathrm{abc}$ & $3.2 \mathrm{a}$ & $41.0 \mathrm{a}$ & $3115.5 \mathrm{a}$ & $95.0 \mathrm{c}$ \\
\hline Embrapa 42 & $18.0 \mathrm{~b}$ & $49.5 \mathrm{abcd}$ & $2.7 \mathrm{bcd}$ & $40.5 \mathrm{a}$ & $2530.0 \mathrm{a}$ & $94.5 \mathrm{c}$ \\
\hline IAC 24-Tucuruí & $20.5 a b$ & $48.0 \mathrm{bcd}$ & $2.4 \mathrm{~d}$ & $36.5 \mathrm{a}$ & $2554.0 \mathrm{a}$ & $100.5 \mathrm{~b}$ \\
\hline IAC 364-Tucuruí III & $19.5 \mathrm{ab}$ & $47.5 \mathrm{~cd}$ & $2.5 \mathrm{~cd}$ & $41.0 \mathrm{a}$ & $3190.0 \mathrm{a}$ & $100.5 \mathrm{~b}$ \\
\hline UFVT 1 Pioneiro & $19.0 \mathrm{ab}$ & $61.0 \mathrm{a}$ & $3.2 \mathrm{ab}$ & $39.5 \mathrm{a}$ & $3133.5 \mathrm{a}$ & $96.0 \mathrm{c}$ \\
\hline VI 98053 & $18.0 \mathrm{~b}$ & $58.5 \mathrm{abc}$ & $3.4 \mathrm{a}$ & $37.5 \mathrm{a}$ & $2842.0 \mathrm{a}$ & $100.5 \mathrm{~b}$ \\
\hline \multirow[t]{2}{*}{ Mean } & 19.2 & 54.2 & 2.9 & 39.3 & 2840.9 & 98.1 \\
\hline & \multicolumn{4}{|c|}{ Cultivation with stress } & & \\
\hline MGS 1 Aliança & $15.7 \mathrm{a}$ & $32.7 \mathrm{a}$ & $2.1 \mathrm{bcd}$ & $28.0 \mathrm{a}$ & $503.3 \mathrm{bcd}$ & $72.0 \mathrm{ab}$ \\
\hline Anahuac 75 & $16.0 \mathrm{a}$ & $28.3 \mathrm{a}$ & $1.7 \mathrm{~d}$ & $27.0 \mathrm{a}$ & $633.0 \mathrm{bc}$ & $76.7 \mathrm{a}$ \\
\hline BRS 254 & $14.7 \mathrm{a}$ & $36.3 \mathrm{a}$ & $2.4 \mathrm{abc}$ & $31.3 \mathrm{a}$ & $1122.0 \mathrm{a}$ & $67.3 \mathrm{~b}$ \\
\hline BRS 264 & $13.3 \mathrm{a}$ & $37.3 \mathrm{a}$ & $2.8 \mathrm{a}$ & $28.0 \mathrm{a}$ & $520.0 \mathrm{bcd}$ & $69.0 \mathrm{~b}$ \\
\hline Embrapa 42 & $15.0 \mathrm{a}$ & $27.7 \mathrm{a}$ & $1.9 \mathrm{~cd}$ & $28.3 \mathrm{a}$ & $374.0 \mathrm{~cd}$ & $68.0 \mathrm{~b}$ \\
\hline IAC 24-Tucuruí & $17.0 \mathrm{a}$ & $30.7 \mathrm{a}$ & $1.8 \mathrm{~d}$ & $27.0 \mathrm{a}$ & $326.0 \mathrm{~d}$ & $77.7 \mathrm{a}$ \\
\hline IAC 364-Tucuruí III & $16.0 \mathrm{a}$ & $33.3 \mathrm{a}$ & $2.1 \mathrm{bcd}$ & $30.0 \mathrm{a}$ & $643.0 \mathrm{bc}$ & $71.3 \mathrm{ab}$ \\
\hline UFVT 1 Pioneiro & $14.0 \mathrm{a}$ & $34.0 \mathrm{a}$ & $2.4 \mathrm{abc}$ & $28.0 \mathrm{a}$ & $466.0 \mathrm{bcd}$ & $73.7 \mathrm{ab}$ \\
\hline VI 98053 & $14.0 \mathrm{a}$ & $35.7 \mathrm{a}$ & $2.6 \mathrm{ab}$ & $31.3 \mathrm{a}$ & $706.7 \mathrm{~b}$ & $73.7 \mathrm{ab}$ \\
\hline \multirow[t]{2}{*}{ Mean } & 15.1 & 32.9 & 2.2 & 28.8 & 588.2 & 72.2 \\
\hline & \multicolumn{4}{|c|}{ Percentage reduction $(\% \mathbf{R})^{(2)}$} & & \\
\hline MGS 1 Aliança & $19(4)$ & $23(1)$ & $5(1)$ & $32(9)$ & $85(6)$ & $23(3)$ \\
\hline Anahuac 75 & $24(7)$ & $53(9)$ & $43(9)$ & $31(7)$ & $67(2)$ & $27(4)$ \\
\hline BRS 254 & $23(6)$ & $40(6)$ & $25(5)$ & $18(2)$ & $62(1)$ & $31(9)$ \\
\hline BRS 264 & $26(8)$ & $37(4)$ & $13(2)$ & $32(8)$ & $83(5)$ & $27(6)$ \\
\hline Embrapa 42 & $17(2)$ & $44(7)$ & $30(8)$ & $30(6)$ & $85(7)$ & $28(7)$ \\
\hline IAC 24-Tucuruí & $17(1)$ & $36(3)$ & $25(7)$ & $26(3)$ & $87(9)$ & $23(1)$ \\
\hline IAC 364-Tucuruí III & $18(3)$ & $30(2)$ & $16(3)$ & $27(4)$ & $80(4)$ & $29(8)$ \\
\hline UFVT 1 Pioneiro & $26(8)$ & $44(8)$ & $25(6)$ & $29(5)$ & $85(8)$ & $23(2)$ \\
\hline VI 98053 & $22(5)$ & $39(5)$ & $24(4)$ & $17(1)$ & $75(3)$ & $27(5)$ \\
\hline Mean & 21 & 39 & 23 & 27 & 79 & 26 \\
\hline
\end{tabular}

${ }^{(1)}$ Means followed by the same letter in the column are not significantly different by the Tukey test at $5 \%$ probability. ${ }^{(2)}$ Numbers in parentheses refer to the classification of the reduction percentages. 
Table 5. Heat Tolerance Indices (Fischer \& Mauer, 1978) for the traits number of spikelets per spike (NSS), number of grains per spike (NGS), number of grains per spikelet (NGSL), 1000-grain weight (TGW), grain yield (YIE) and cycle to maturity (CYC) of wheat cultivars grown in environment with and without heat stress. Viçosa (MG), $2012^{(1)}$

\begin{tabular}{lllllll}
\hline Cultivar & \multicolumn{1}{c}{ NSS } & NGS & NGSL & TGW & YIE & CYC \\
\hline MGS 1 Aliança & $0.91(\mathrm{M})$ & $0.57(\mathrm{M})$ & $0.18(\mathrm{~T})$ & $1.18(\mathrm{~S})$ & $1.07(\mathrm{~S})$ & $0.89(\mathrm{M})$ \\
Anahuac 75 & $1.12(\mathrm{~S})$ & $1.37(\mathrm{~S})$ & $1.86(\mathrm{~S})$ & $1.15(\mathrm{~S})$ & $0.85(\mathrm{M})$ & $1.00(\mathrm{M})$ \\
BRS 254 & $1.06(\mathrm{~S})$ & $1.04(\mathrm{~S})$ & $1.07(\mathrm{~S})$ & $0.65(\mathrm{M})$ & $0.78(\mathrm{M})$ & $1.17(\mathrm{~S})$ \\
BRS 264 & $1.22(\mathrm{~S})$ & $0.95(\mathrm{M})$ & $0.60(\mathrm{M})$ & $1.18(\mathrm{~S})$ & $1.05(\mathrm{~S})$ & $1.04(\mathrm{~S})$ \\
Embrapa 42 & $0.78(\mathrm{M})$ & $1.11(\mathrm{~S})$ & $1.28(\mathrm{~S})$ & $1.12(\mathrm{~S})$ & $1.07(\mathrm{~S})$ & $1.06(\mathrm{~S})$ \\
IAC 24-Tucuruí & $0.80(\mathrm{M})$ & $0.90(\mathrm{M})$ & $1.08(\mathrm{~S})$ & $0.97(\mathrm{M})$ & $1.10(\mathrm{~S})$ & $0.85(\mathrm{M})$ \\
IAC 364-Tucuruí III & $0.84(\mathrm{M})$ & $0.78(\mathrm{M})$ & $0.69(\mathrm{M})$ & $1.00(\mathrm{M})$ & $1.01(\mathrm{~S})$ & $1.11(\mathrm{~S})$ \\
UFVT 1 Pioneiro & $1.23(\mathrm{~S})$ & $1.13(\mathrm{~S})$ & $1.09(\mathrm{~S})$ & $1.08(\mathrm{~S})$ & $1.07(\mathrm{~S})$ & $0.87(\mathrm{M})$ \\
VI 98053 & $1.04(\mathrm{~S})$ & $0.98(\mathrm{M})$ & $0.98(\mathrm{M})$ & $0.61(\mathrm{M})$ & $0.95(\mathrm{M})$ & $1.00(\mathrm{M})$ \\
\hline
\end{tabular}

${ }^{(1)} \mathrm{S}$ : Sensitive to heat; M: moderately tolerant to heat; T: heat tolerant.

According to Dias \& Lindon (2009), the capacity to increase the rate of photosynthate translocation to grains is one of the mechanisms that confer heat tolerance to wheat, which is more advantageous than the duration of the grain filling period. Therefore, it is likely that the productive superiority of BRS 254 is due to the high rate of translocation, which compensates for the cycle shortening and sustains grain filling. In addition to account for the final grain yield, stability of the grain mass in heat stress environments is important in determining grain quality (Khanna-Chopra \& Viswanathan, 1999).

The cultivar MGS 1 Aliança is a benchmark for heat tolerance, but did not show the expected production performance in the stress condition. Grain yield was low because of its susceptibility to heat during the grain filling stage, a fact so far unknown and demonstrated by the reduction percentage in 1000-grain weight (Table 4). Despite being a rainfed cultivar, with sowing in the summer in Minas Gerais, the crop is limited to areas with altitude above $800 \mathrm{~m}$, with prevailing temperatures during grain filling lower than those recorded in this experiment. The sensitivity of this cultivar during grain filling is confirmed by the positive response obtained in stress-free environments (Table 4).

The variation in genotype performance due to heat stress intensity is one of the main difficulties in breeding for heat tolerance (Souza et al., 2012). Differences in environments with high temperature, in association with different crop stages in which the stress occurs, is one of the factors considered in wheat breeding for heat tolerance in programs developed by CIMMYT (International Maize and Wheat Improvement Center High Temperature Wheat Yield Trial) (Reynolds et al., 2001).

Cultivar Anahuac 75 showed the largest percentage reduction for yield components. However, it sustained stable grain yield, with reduction greater only than BRS 254 (Table 4). IFM (Table 5) indicated this cultivar is sensitive to heat for yield components and moderately tolerant for grain yield. This yield stability may be due to a greater tillering capacity under stress, an inherent characteristic of this cultivar. Despite the yield stability, the average grain yield was low. The low yield is explained by the fact that this cultivar was recommended in 1981, hence the lower yield potential compared to the other cultivars. However, its potential as a source of genes for heat tolerance is recognized (Souza \& Ramalho, 2001; Cargnin et al., 2006). One example is the performance of BRS 254, which was obtained from the crossing between Embrapa 22 and Anahuac 75.

These findings show that these cultivars are potentially useful as a source of genes to improve heat tolerance in wheat breeding programs and allow breeders to combine favorable alleles present in the different cultivars in one offspring.

\section{CONCLUSIONS}

Heat stress reduces wheat grain yield.

Among the traits evaluated, the number of grains per spike is the yield component that is mostly reduced under heat stress conditions.

The genotypes differ in the developmental stage at which they are more tolerant to heat stress.

\section{REFERENCES}

Acevedo E, Nachit M \& Ferrara GO (1991) Effects of heat stress on wheat and possible selection tools for use in breeding for tolerance. In: International Conference: Wheat for the nontraditional warm areas, Foz do Iguaçu. Proceedings, CIMMYT. p.401-421.

Albrecht JC, Vieira EA, Só e Silva M, Andrade JMV, Scheeren PL, Trindade MG, Sobrinho JS, Sousa CNA, Reis WP, Ribeiro Júnior WQ, Fronza V, Cargnin A \& Yamanaka CH (2007) Adaptabilidade e estabilidade de genótipos de trigo irrigado no Cerrado do Brasil Central. Pesquisa Agropecuária Brasileira, 42:1727-1734.

Assad MT \& Paulsen GM (2002) Genetic changes in resistance to environmental stresses by U.S. Great Plains wheat cultivars. Euphytica, 128:87-96. 
Cargnin A, Souza MA, Rocha VS, Machado JC \& Piccini E (2006) Tolerância ao estresse térmico em genótipos de trigo. Pesquisa Agropecuária Brasileira, 41:1269-1276.

Comissão Brasileira de Trigo e Triticale (2011) Informações técnicas para trigo e triticale - safra 2012. Dourados, Embrapa Agropecuária Oeste. 204 p

CONAB - Companhia Nacional de Abastecimento (2014) Acompanhamento da safra brasileira de grãos - Safra 2013/2014 - Décimo segundo levantamento. Brasília, CONAB. 127p.

Cunha GR, Ventimiglia LM, Haas JC, Garcia R \& MacManey M (1996) Composição do rendimento de grãos em genótipos de trigo argentino. Pesquisa Agropecuária Gaúcha, 2:155-162.

Denyer K, Hylton CM \& Smith AM (1994) The effect of high temperature on starch synthesis and the activity of starch synthase. Australian Journal of Plant Physiology, 21:783-789.

Dias AS \& Lidon FC (2009) Evaluation of grain filling rate and duration in bread and durum wheat, under heat stress after anthesis. Journal of Agronomy and Crop Science, 195:137-147.

Farooq J, Khaliq I, Ali MA, Kashif M, Rehman A, Naveed M, Ali Q, Nazeer W \& Farooq A (2011a) Inheritance pattern of yield attributes in spring wheat at grain filling stage under different temperature regimes. Australian Journal of Crop Science, 5:1745-1753.

Farooq M, Bramley H, Palta JA \& Siddique KHM (2011b) Heat stress in wheat during reproductive and grain-filling phases. Critical Reviews in Plant Sciences, 30:01-17.

Fischer RA \& Mauer R (1978) Drought resistance in spring wheat cultivars. I. Grain yield response. Australian Journal of Agricultural Research, 29:897-912.

Khanna-Chopra R \& Viswanathan C (1999) Evaluation of heat stress tolerance in irrigated environment of T. aestivum and related species. I. Stability in yield and yield components. Euphytica, 106:169-180.

Labuschagne MT, Elago O \& Koen E (2009) The influence of temperature extremes on some quality and starch characteristics in bread, biscuit and durum wheat. Journal of Cereal Science, 49:184-189.

Lillemo M, Ginkel MV, Trethowan RM, Hernandez E \& Crossa J (2005) Differential Adaptation of CIMMYT Bread Wheat to Global High Temperature Environments. Crop Science, 45:2443-2453.

McMaster GS (1997) Phenology, development, and growth of the whea (Triticum aestivum L.) shoot apex: a review. Advances in Agronomy, 59:63-118.

Mohammadi V, Zali AA \& Bihamta MR (2008) Mapping QTLS for heat tolerance in wheat. Journal of Agricultural Science and Technology, 10:261-267.

Moraes AF, Bonfa AP, Quadros WRJ, Ramos MLG, Albrecht JC \& Amábile RF (2008) Viabilidade do trigo cultivado no verão do Brasil Central. In: IX Simpósio Nacional do Cerrado e II Simpósio Internacional de Savanas Tropicais, Brasília. Anais, EMBRAPA/CPAC. p.1-5.

Oliveira DM, Souza MA, Rocha VS \& Assis JC (2011) Desempenho de genitores e populações segregantes de trigo sob estresse de calor. Bragantia, 70:25-32.
Ortiz R, Sayre KD, Govaerts B, Gupta R, Subbarao GV, Ban T, Hodson D, Dixon JM, Ortiz-Monasterio JI \& Reynolds M (2008) Climate change: Can wheat beat the heat? Agriculture, Ecosystems and Environment, 126:46-58.

Pimentel-Gomes F (2000) Curso de Estatística Experimental. Piracicaba, Nobel. 477p.

Rahman MA, Chikushi J, Yoshida S \& Karim AJMS (2009) Growth and yield components of wheat genotypes exposed to high temperature stress under control environment. Bangladesh Journal of Agricultural Research, 34:361-372.

Reynolds MP, Balota M, Delgado MIB, Amani I \& Fischer RA (1994) Physiological and Morphological Traits Associated With Spring Wheat Yield Under Hot, Irrigated Conditions. Australian Journal of Plant Physiology, 21:717-730.

Reynolds MP, Nagarajan S, Razzaque MA \& Ageeb OAA (2001) Heat tolerance. In: Reynolds M, Ortiz-Monasterio JI \& Mcnab A (Eds.) Application of Physiology in Wheat Breeding. México, CIMMYT. p.124-135.

SAS Institute (2003) Statistical Analysis System. Versão 9.1. Cary, Statistical Analysis System Institute.

Shah NH \& Paulsen GM (2003) Interaction of drought and high temperature on photosynthesis and grain-filling of wheat. Plant and Soil, 257:219-226

Shpiler L \& Blum A (1986) Differential reaction of wheat cultivars to hot environments. Euphytica, 35:483-492.

Souza MA \& Pimentel AJB (2013) Estratégias de seleção para melhoramento do trigo com tolerância ao estresse por calor. Informe Agropecuário, 34:30-39.

Souza MA \& Ramalho MAP (2001) Controle genético e tolerância ao estresse de calor em populações híbridas e em cultivares de trigo. Pesquisa Agropecuária Brasileira, 36:1245-1253.

Souza MA, Pimentel AJB \& Ribeiro G (2012) Breeding for heat-stress tolerance. In: Fritshe-Neto R \& Borém A (eds.) Plant breeding for abiotic stress tolerance. Berlin, Springer. p.137-156.

Stone PJ \& Nicolas ME (1995) Comparison of sudden stress with gradual exposure to high temperature during filling in two varieties differing in heat tolerance. I. Grain growth. Australian Journal of Plant Physiology, 22:935-944.

Taiz L \& Zeiger E (2004) Fisiologia vegetal. $3^{\mathrm{a}}$ ed. Porto Alegre, Artmed. $719 \mathrm{p}$.

Wahid A, Gelani S, Ashraf M \& Foolad MR (2007) Heat tolerance in plants: An overview. Environmental and Experimental Botany, 61:199223.

Wardlaw IF, Dawson IA \& Munibi P (1989) The tolerance of wheat to high temperatures during reproductive growth: II. Grain development. Australian Journal of Agricultural Research, 40:15-24.

Yildirim M \& Bahar B (2010) Responses of some wheat genotypes and their $\mathrm{F}_{2}$ progenies to salinity and heat stress. Scientific Research and Essays, 5:1734-1741.

Zadoks JC, Chang TT \& Konzak CF (1974) A decimal code for the growth stages of cereals. Weed Research, 14:415-421. 